\title{
POTENSI SIMPANAN KARBON PADANG LAMUN DI PANTAI POKEMON, KARIMUNJAWA
}

\section{CARBON STORAGE POTENTIAL OF SEAGRASS MEADOWS IN POKEMON BEACH, KARIMUNJAWA}

\author{
Desti Nurul Ramadona, Churun Ain*, Sigit Febrianto, Suryanti, \& Nurul Latifah \\ Departemen Sumberdaya Akuatik, Fakultas Perikanan dan Ilmu Kelautan, \\ Universitas Diponegoro, Semarang, 50275, Indonesia \\ *E-mail: churunain@ lecturer.undip.ac.id
}

\begin{abstract}
Increased greenhouse gas $(\mathrm{GHG})$ emissions, especially carbon dioxide $\left(\mathrm{CO}_{2}\right)$, caused global warming. Therefore, mitigation of $\mathrm{CO}_{2}$ emissions is needed by utilizing seagrass potential as carbon storage in biomass. This study aims to determine the carbon storage of above and below ground seagrass in Pokemon Beach in August 2020. The research method used a survey method and descriptive explorative. Samples were taken from 3 stations with line and quadrant transects using the purposive sampling method. Measurement of water quality parameters was performed in-situ. Analysis of seagrass carbon storage was measured using the loss on ignition (LOI) method. The results showed that there are 4 different types of seagrass: Enhalus acoroides, Thalasssia hemprichii, Cymodocea rotundata, and Halophila ovalis, with T. hemprichii dominating. The total density was $295.62 \mathrm{ind} / \mathrm{m}^{2}$, with a $21.29 \%$ coverage rate. The overall biomass was $74.42 \mathrm{~g} / \mathrm{m}^{2}$, with the above ground biomass of $35.80 \mathrm{~g} / \mathrm{m}^{2}$ and the below ground at $38.62 \mathrm{~g} / \mathrm{m}^{2}$. Carbon storage amounted to 0.23 tons C/ha, consisting of above ground 0.10 tons $C / h a$ and below ground of 0.13 tons C/ha. The total carbon stock reached 1.13 tons $C$ in the seagrass area of $4903 \mathrm{ha}$, with an above ground carbon stock of 0.51 tons $C$ and below ground of 0.62 tons $C$. In general, the below ground seagrass in Pokemon Beach was the largest, storing more carbon.
\end{abstract}

Keywords: carbondioxide $\left(\mathrm{CO}_{2}\right)$, carbon storage, Karimunjawa National Park, seagrass

\begin{abstract}
ABSTRAK
Peningkatan emisi Gas Rumah Kaca (GRK) terutama karbondioksida $\left(\mathrm{CO}_{2}\right)$ menyebabkan pemanasan global. Oleh karena itu diperlukan mitigasi emisi $\mathrm{CO}_{2}$ dengan memanfaatkan potensi lamun sebagai penyimpan karbon dalam bentuk biomassa. Tujuan penelitian ini untuk mengetahui kemampuan lamun jaringan atas dan jaringan bawah dalam menyimpan karbon di perairan Pantai Pokemon pada Agustus 2020. Metode penelitian yang digunakan yaitu metode survei dan deskriptif eksploratif. Sampel diambil dari 3 stasiun pengamatan dengan line dan kuadrant transect menggunakan metode purposive sampling. Pengukuran parameter kualitas perairan dilakukan secara insitu. Analisis simpanan karbon lamun diukur menggunakan metode pengabuan atau loss on ignition (LOI). Hasil penelitian menunjukkan terdapat 4 jenis lamun yaitu Enhalus acoroides, Thalassia hemprichii, Cymodocea rotundata, dan Halophila ovalis dengan jenis T. hemprichii yang mendominasi. Total kerapatan sebesar 295,62 ind $/ \mathrm{m}^{2}$ dan total penutupan yaitu 21,29\%. Biomassa secara keseluruhan sebesar $74,42 \mathrm{gbk} / \mathrm{m}^{2}$ dengan biomassa jaringan atas sebesar $35,80 \mathrm{gbk} / \mathrm{m}^{2}$ dan jaringan bawah sebesar $38,62 \mathrm{gbk} / \mathrm{m}^{2}$. Simpanan karbon sebesar 0,23 ton $\mathrm{C} /$ ha dengan jaringan atas sebesar 0,10 ton $\mathrm{C} / \mathrm{ha}$ dan jaringan bawah 0,13 ton $\mathrm{C} / \mathrm{ha}$. Total stok karbon mencapai 1,13 ton $\mathrm{C}$ dalam luasan padang lamun sebesar 4,903 ha dengan stok karbon jaringan atas bernilai 0,51 ton $C$ dan jaringan bawah sebesar 0,62 ton C. Secara umum lamun jaringan bawah di Pantai Pokemon lebih besar menyimpan karbon.
\end{abstract}

Kata kunci: karbondioksida $\left(\mathrm{CO}_{2}\right)$, lamun, simpanan karbon, Taman Nasional Karimunjawa 


\section{PENDAHULUAN}

Meningkatnya aktivitas manusia seperti penggunaan bahan bakar fosil serta pembukaan lahan yang terjadi sejak Revolusi Industri menjadi sumber tambahan bagi gas rumah kaca (GRK) di atmosfer (Aji et al., 2020). GRK terdiri dari karbondioksida $\left(\mathrm{CO}_{2}\right)$, metana $\left(\mathrm{CH}_{4}\right)$, dinitrogen oksida $\left(\mathrm{N}_{2} \mathrm{O}\right)$, dan gas yang mengandung klorofluorokarbon (CFC) (Ganefiani et al., 2019). Menurut national oceanic and atmospheric administration (NOAA) bahwa $\mathrm{CO}_{2}$ sangat efektif dalam menjebak panas dengan waktu tinggal paling lama di atmosfer sehingga menyebabkan peningkatan suhu secara global. Karbondioksida sendiri merupakan salah satu komponen GRK utama di atmosfer yang berperan dalam siklus biogeokimia pada perairan (Prasetyawan et al., 2017). Emisi $\mathrm{CO}_{2}$ di atmosfer dapat diminimalisir dengan cara memanfaatkan kemampuan wilayah pesisir sebagai penyerap karbon alami melalui fitoplankton dan tumbuhan air seperti lamun (Indriani et al., 2017).

Lamun memiliki potensi menyerap karbon (carbon sink) melalui proses fotosintesis dan menyimpan karbon dalam bentuk biomassa pada jaringan atas (daun) dan jaringan bawah (akar dan rhizoma) tubuhnya dengan jangka waktu yang cukup lama (Khairunnisa et al., 2018). Secara morfologi dan anatomi, lamun (seagrass) memiliki jaringan berpembuluh dengan bagian-bagian tubuh yang jelas seperti daun, batang, rhizoma, akar, dan bunga sehingga lamun merupakan tumbuhan air tingkat tinggi (Anthophyta) (Harimbi et al., 2019). Kemampuan ekosistem lamun dalam menyimpan $\mathrm{CO}_{2}$ dapat mencapai 83.000 ton $\mathrm{C} / \mathrm{km}^{2}$, hasil tersebut menunjukkan angka yang lebih besar dari penyimpanan karbon oleh vegetasi darat yang hanya berkisar 30.000 ton $\mathrm{C} / \mathrm{km}^{2}$ (Fourqurean et al., 2012; Aji et al., 2020).

Berdasarkan penelitian dari Hartati et al. (2017) di perairan Karimunjawa tepatnya di Pulau Menjangan Kecil dan Pulai Sintok menyebutkan bahwa kedua pulau tersebut memiliki total simpanan karbon masingmasing sebesar 32,18 ton $\mathrm{C} /$ ha dan 4,18 ton $\mathrm{C} / \mathrm{ha}$. Hasil penelitian lainnya yaitu dari Ganefiani et al. (2019) menunjukkan bahwa simpanan karbon di Pelabuhan Karimunjawa sebesar 0,50 ton $\mathrm{C} /$ ha dan di Pantai Pancuran bernilai 0,73 ton $\mathrm{C} / \mathrm{ha}$. Sedangkan penelitian yang dilakukan oleh Aji et al. (2020) di Pulau Nyamuk, Karimunjawa memperoleh hasil simpanan karbon sebesar 200,14 ton C/ha.

Hasil dari berbagai penelitian yang telah dilakukan pada beberapa lokasi di Kepulauan Karimunjawa tersebut menjadi dasar tujuan dilakukan penelitian mengenai potensi simpanan karbon lamun di perairan Pantai Pokemon yang menjadi salah satu destinasi wisata bahari. Penelitian ini berfokus pada kemampuan lamun sebagai jaringan hidup dalam menyimpan karbon yang didukung dengan data kondisi lingkungan perairan Pantai Pokemon.

\section{METODE PENELITIAN}

\subsection{Materi}

Materi yang digunakan dalam penelitian ini adalah sampel lamun dari Pantai Pokemon sebanyak 27 titik penelitian pada bulan Agustus 2020, parameter kualitas perairan $(\mathrm{pH}$, suhu, intensitas cahaya, oksigen terlarut, karbondioksida terlarut, dan salinitas) serta biomassa dan simpanan karbon. Proses pengujian karbon lamun dilakukan di Laboratorium Fakultas Peternakan dan Pertanian, Universitas Diponegoro.

\subsection{Metode}

Metode yang digunakan untuk mengetahui kondisi lapangan yaitu menggunakan metode survei dan deskriptif eksploratif yang dapat menggambarkan sebab akibat dari kondisi di lapangan (Wicaksono et al., 2012). Metode lainnya yang digunakan yaitu metode purposive sampling sebagai metode penentuan lokasi penelitian secara sengaja karena dianggap 
representatif (Allifah \& Rosmawati, 2018). Penelitian ini berlokasi di Pantai Pokemon dengan 3 stasiun (Gambar 1). Setiap stasiun penelitian terdiri dari 3 line tansect sepanjang $50 \mathrm{~m}$ yang dibentangkan ke arah laut tegak lurus dengan garis pantai. Hal ini dilakukan mulai dari lamun pertama yang ditemukan pada perairan yang berada paling dekat dengan garis pantai (Sembiring et al., 2020). Jarak antar line transect di stasiun penelitian yaitu $25 \mathrm{~m}$ dengan setiap line transect terdapat 3 kuadrant transect (Gambar 2). Kuadrant transect yang digunakan berukurann $50 \times 50 \mathrm{~cm}^{2}$ yang terbagi menjadi 4 sub kuadran dengan ukuran $25 \times 25 \mathrm{~cm}^{2}$ (Wicaksono et al., 2012).

Pengamatan lamun dilakukan pada saat kondisi air laut surut dengan mengamati kerapatan, penutupan, dan jenis lamun yang berada dalam kuadrant transect

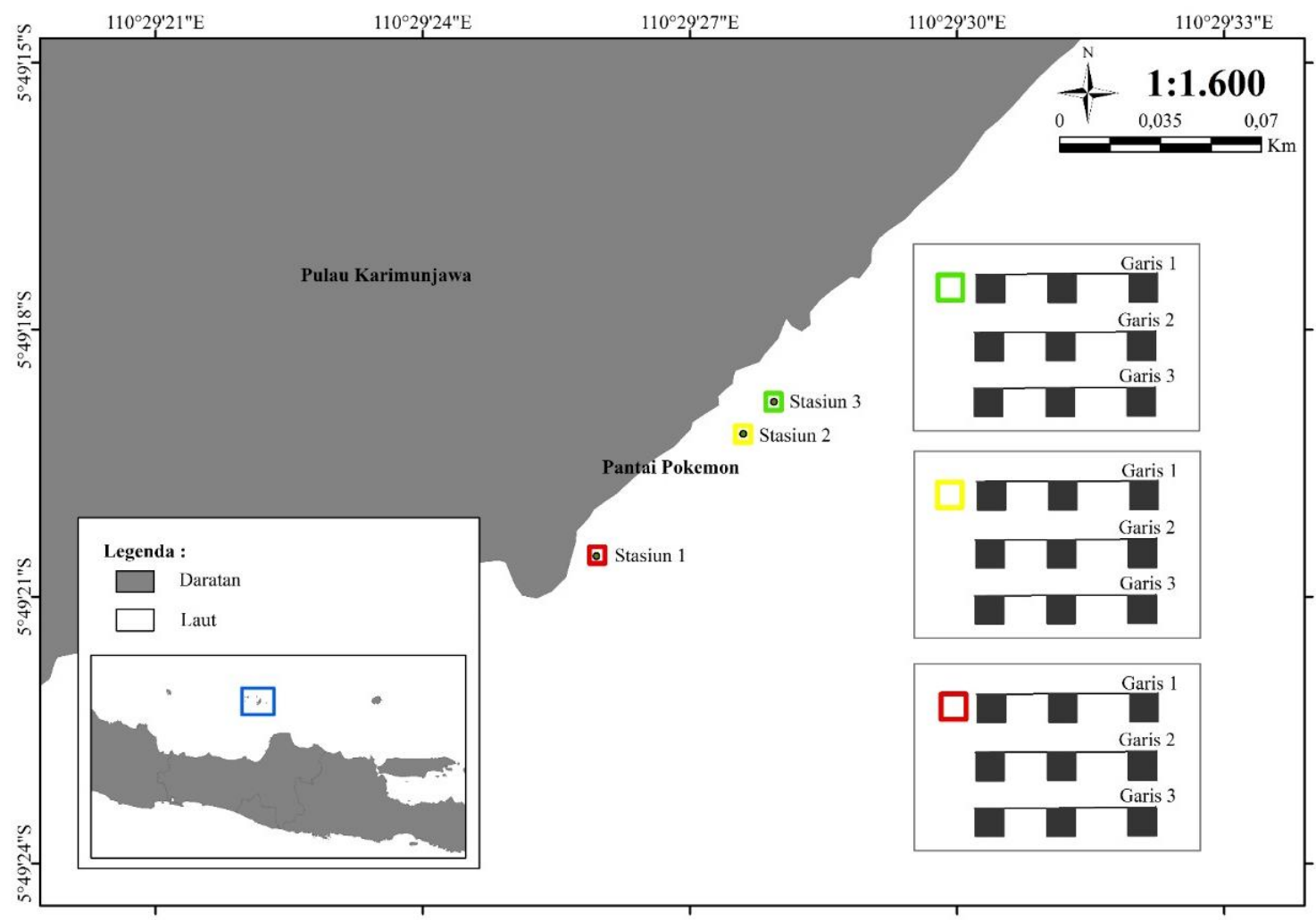

Gambar 1. Lokasi penelitian, Karimunjawa 2020.

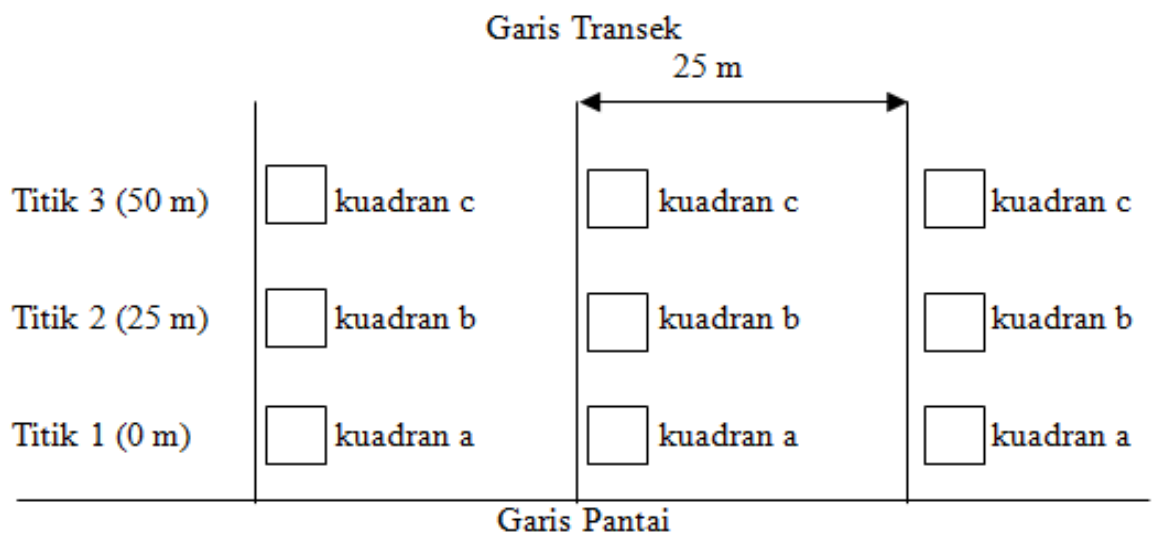

Gambar 2. Penempatan garis dan kuadran transek. 
(Ganefiani et al., 2019). Menurut Hidayah et al. (2019) identifikasi jenis lamun dilakukan dengan mengamati ciri khusus yang terdapat pada daun, batang, rhizoma, bunga dan akar lamun. Foto secara tegak lurus dari atas setiap kuadran yang telah terpasang agar kondisi lamun dalam transek dapat terlihat secara keseluruhan dan memudahkan dalam pengamatan penutupan lamun (Mashoreng et al., 2018). Pengamatan lamun untuk mengetahui kerapatannya dilakukan dengan mengamati lamun dalam satu tegakan utuh yaitu dari akar hingga daun lamun (Hidayah et al., 2019). Satu tegakan dihitung jika bagian akar, batang dan daun berada dalam kuadrant transect. Seluruh pengukuran parameter kualitas perairan dilakukan secara insitu dengan pengukuran karbondioksida dan oksigen terlarut menggunakan metode titrasi untuk memperoleh hasil yang lebih akurat (Bayu et al., 2018).

Pengambilan sampel lamun menggunakan metode line dan kuadrant transect untuk menentukan titik padang lamun yang akan diamati. Metode ini berdasarkan dari buku Panduan Identifikasi Potensi dan Pemantauan Biofisik Kawasan Konservasi Perairan, Pesisir dan Pulau-Pulau Kecil dan modifikasi berdasarkan metode seagrass watch (Ganefiani et al., 2019). Bagu et al. (2020) menjelaskan bahwa pengambilan sampel lamun dilakukan dengan memotong bagian rhizoma yang menjalar dengan tegakan lainnya lalu mengambil beberapa tegakan lamun tersebut dari bagian akar hingga daun. Sampel yang diambil harus berada dalam kuadrant transect sehingga dapat mewakili kondisi lamun di titik penelitian lalu disimpan dalam plastik zipper untuk menjaga kesegaran dari sampel lamun yang diambil (Setiawati et al., 2018).

\subsection{Analisis Data}

\subsubsection{Kerapatan Lamun dan Persentase Penutupan}

Kerapatan menggambarkan banyaknya suatu individu tertentu dalam suatu wilayah (Bagu et al., 2020) yang dapat diketahui menggunakan persamaan sebagai berikut.

$D_{i}=$ Jumlah jenis $k e-i \times 4$

Keterangan: $D_{i}=$ kerapatan jenis ke-i $\left(\mathrm{ind} / \mathrm{m}^{2}\right), \quad 4=$ konstanta untuk konversi kuadran transek $50 \times 50 \mathrm{~cm}^{2}$ ke $1 \mathrm{~m}^{2}$.

Persentase penutupan jenis lamun dilakukan disetiap kuadrant transect dengan persamaan sebagai berikut (Rahmawati et al., 2014).

\section{Persentase Penutupan (\%) = Epenutupan semua sub kuadrant(\%) $\sum$ sub kuadrant}

\subsubsection{Struktur Komunitas Lamun}

Nilai dari indeks keanekaragaman berbanding lurus dengan kekayaan padang lamun dan kestabilan di lokasi tersebut (Yusuf et al., 2013a). Indeks keanekaragaman ditentukan berdasarkan persamaan Shannon-Wiener (Samson et al., 2020) sebagai berikut.

$H^{\prime}=-\sum_{i=1}^{n}(P i \operatorname{Ln} P i)$

$P_{i}=\frac{n i}{N}$

Keterangan: $H^{\prime}=$ nilai indeks keanekaragaman, $P_{i}=$ proporsi frekuensi jenis ke-i terhadap jumlah total, $n_{i}=$ jumlah individu jenis ke-i, $N=$ jumlah total individu.

Dengan kriteria:

$\mathrm{H}^{\prime} \leq 1 \quad=$ Keanekaragaman rendah

$1<\mathrm{H}^{\prime} \leq 3 \quad=$ Keanekaragaman sedang

$\mathrm{H}^{\prime}>3=$ Keanekaragaman tinggi.

Semakin tinggi nilai indeks keseragaman menunjukkan di wilayah padang lamun tersebut memiliki banyak jenis lamun yang berbeda-beda (Yusuf et al., 2013a). Nilai indeks keseragaman dapat menggunakan persamaan Simpson's Index (Hartati et al., 2017) sebagai berikut.

$E=\frac{H^{s}}{\text { Hmax }}$ 
$H_{\max }=\operatorname{Ln} S$.

Keterangan: $E=$ nilai indeks keseragaman, $H_{\max }=$ nilai keanekaragaman maksimum, $S=$ jumlah spesies.

Dengan kriteria:

$\mathrm{E}<0,4=$ keseragaman rendah

$0,4 \leq \mathrm{E}<0,6=$ keseragaman sedang

$\mathrm{E} \geq 0,6 \quad=$ keseragaman tinggi.

Indeks dominansi menunjukkan adanya jenis lamun yang mendominasi di wilayah padang lamun. Penentuan nilai indeks dominansi menggunakan persamaan Simpson (Ganefiani et al., 2019) sebagai berikut.

$D=\sum_{i=1}^{n}\left(P i^{2}\right)$

Keterangan: $D=$ nilai indeks dominansi

Dengan kriteria:

$\mathrm{D} \approx 0$ = tidak ada jenis yang mendominasi

$\mathrm{D} \approx 1$ = ada jenis yang mendominasi

\subsubsection{Biomassa Lamun}

Pengukuran biomassa lamun dilakukan dengan memisahkan lamun bagian atas substrat (above ground) yaitu daun dengan bawah substrat (below ground) yaitu akar dan rhizoma yang dipotong hingga ukuran terkecil (Bagu et al., 2020). Menurut Rustam et al. (2019a) potongan jaringan lamun dimasukkan ke oven selama 12-24 jam dalam suhu $105^{\circ} \mathrm{C}$, hal ini dilakukan untuk menghilangkan kandungan air dalam jaringan. Nilai biomassa dari lamun dapat menggunakan persamaan sebagai berikut (Harimbi et al., 2019).

$B=W \times D$

Keterangan: $B=$ biomassa lamun $\left(\mathrm{gbk} / \mathrm{m}^{2}\right)$, $W=$ berat kering suatu tegakan lamun (gbk/ind), $D i=$ kerapatan lamun (ind $/ \mathrm{m}^{2}$ ).

\subsubsection{Simpanan Karbon}

Simpanan karbon pada lamun diukur menggunakan metode pengabuan atau loss on ignition (LOI) yang bertujuan untuk mengetahui simpanan karbon dari jaringan lamun. Pengukuran simpanan karbon dilakukan pada jenis lamun yang dominan pada setiap kuadrant transect dan jenis yang tidak dominan dari setiap stasiun. Menurut Helrich (1990) bahwa persamaan yang digunakan yaitu:

Kadar $A b u=\frac{c-a}{b-a} \times 100 \%$

\section{Kadar Bahan Organik = $\frac{[(b-a)-(c-a)]}{(b-a)} \times 100 \%$}

Kadar Karbon Organik (\%) = Kadar Bahan Organik (\%)

$$
1,724
$$

Keterangan: $a=$ berat cawan, $b=$ berat cawan + berat kering jaringan lamun, $c=$ berat cawan + berat abu jaringan lamun, 1,724= konstanta nilai bahan organik.

Nilai simpanan karbon diperoleh dengan menggunakan nilai biomassa lamun dan persentase karbon organik dalam bentuk desimal. Berdasarkan SNI 7724 (2011) tentang pengukuran dan perhitungan cadangan karbon maka pengukuran simpanan karbon dilakukkan dengan persamaan sebagai berikut.

\section{Simpanan Karbon (ton C/ha) $=$ $B \times$ Persentase Karbon (desimal) 100}

Keterangan: $100=$ konversi dari $\mathrm{g} \mathrm{C} / \mathrm{m}^{2}$ menjadi ton $\mathrm{C} / \mathrm{ha}$.

Nilai stok karbon lamun berhubungan dengan luasan padang lamun dan rata-rata nilai simpanan karbon (Aji et al., 2020). Pengukuran stok karbon dilakukan menggunakan persamaan sebagai berikut (Bagu et al., 2020).

$C_{t}=\Sigma(L i \times C i)$

Keterangan: $C t=$ karbon total, $L i=$ luas 
padang lamun, $C i=$ rata-rata stok karbon.

\section{HASIL DAN PEMBAHASAN}

\subsection{Kondisi Perairan Pantai Pokemon}

Berdasarkan hasil pengukuran kualitas perairan maka kondisi perairan di Pantai Pokemon tergolong baik. Hal ini ditandai dengan ditemukannya teripang jenis Holothuria atra dan ikan-ikan kecil yang merupakan biota asosiasi dengan padang lamun (Oktamalia et al., 2016). Pantai Pokemon memiliki substrat dasar pasir dan pecahan karang, hasil ini sesuai dengan penelitian dari Aji et al. (2020) yang menyatakan Pantai Pokemon memiliki karakteristik substrat pecahan karang bercampur pasir dengan gugusan pohon kelapa di sepanjang pantai. Hasil pengukuran suhu perairan Pantai Pokemon tidak berbeda jauh pada setiap line transect dan sesuai dengan baku mutu perairan untuk pertumbuhan lamun di wilayah tropis meskipun pada nilai salinitas berada di bawah baku mutu tetapi berdasarkan Keputusan Menteri Negara dan Lingkungan Hidup Nomor 51 Tahun 2004 tentang Baku Mutu Air Laut penurunan nilai salinitas yang tidak melebihi 5\% masih tergolong aman untuk lamun. Nilai suhu perairan dan salinitas dalam penelitian ini jauh lebih rendah jika dibandingkan dengan hasil pengukuran kualitas perairan di Pantai Pokemon yang dilakukan oleh Sembiring et al. (2020) yang memperoleh hasil suhu perairan sekitar $33-34{ }^{\circ} \mathrm{C}$ dan salinitas sebesar 33-34\%o. Hasil pengukuran parameter kualitas perairan diperoleh sebagai berikut (Tabel 1).

\subsection{Kerapatan Lamun dan Persentase Penutupan}

Berdasarkan dari identifikasi lamun di Pantai Pokemon terdapat 4 jenis lamun yang ditemukan yaitu Enhalus acoroides, Thalassia hemprichii, Cymodocea rotundata, dan Halophila ovalis. Jenis-jenis lamun yang selalu muncul di ketiga stasiun adalah jenis $T$. hemprichii dan $H$. ovalis. Jenis lamun yang ditemukan tersebut sedikit berbeda dengan penelitian sebelumnya yang hanya ditemukan 3 jenis lamun di Pantai Pokemon yaitu Halodule pinifolia, E. acoroides dan $H$. ovalis (Sembiring et al., 2020). Dari penelitian Aji et al. (2020) terdapat 5 jenis lamun di Pantai Pokemon yaitu E. acoroides, C. rotundata, Halodule uninervis, $H$. ovalis, dan Halophila minor. Perbedaan ini dapat dikarenakan perbedaan titik stasiun penelitian dan waktu penelitian yang menyebabkan terjadinya perbedaan kondisi lingkungan perairan. Mengacu pada hasil suhu perairan dalam penelitian Sembiring et al. (2020) yang melebihi baku mutu yaitu 33$34{ }^{\circ} \mathrm{C}$ dapat menyebabkan lamun mudah stres dan mengalami kematian (Yunitha et al., 2014).

Tabel 1. Parameter kualitas perairan Pantai Pokemon.

\begin{tabular}{|c|c|c|c|c|c|c|c|c|c|c|}
\hline \multirow{3}{*}{ Parameter } & \multirow{3}{*}{$\mathrm{BM}$} & \multicolumn{3}{|c|}{ Stasiun 1} & \multicolumn{4}{|c|}{ Stasiun 2} & \multicolumn{2}{|c|}{ Stasiun 3} \\
\hline & & Garis & Garis & Garis & Garis & Garis & Garis & Garis & Garis & Garis \\
\hline & & 1 & 2 & 3 & 1 & 2 & 3 & 1 & 2 & 3 \\
\hline DO (mg/l) & $>5$ & 6,8 & 7,2 & 6,8 & 6 & 5,6 & 5,6 & 7,4 & 7,2 & 6,8 \\
\hline $\mathrm{pH}$ & $7-8,5$ & 7 & 7 & 7 & 7 & 7 & 7 & 7 & 7 & 7 \\
\hline Salinitas (\%o) & $33-34 \%$ & 29 & 29 & 29 & 28 & 28 & 28 & 27 & 27 & 27 \\
\hline Suhu air $\left({ }^{\circ} \mathrm{C}\right)$ & $28-30^{\circ} \mathrm{C}$ & 29 & 29 & 29 & 30 & 30 & 30 & 30 & 30 & 30 \\
\hline $\begin{array}{l}\text { Intensitas } \\
\text { Cahaya (lux) }\end{array}$ & - & 87500 & 85900 & 87000 & 92200 & 91600 & 90500 & 80700 & 79800 & 81300 \\
\hline $\mathrm{CO} 2$ air $(\mathrm{mg} / \mathrm{l})$ & - & 19,8 & 13,86 & 17,82 & 16,83 & 19,8 & 17,82 & 13,86 & 12,87 & 15,84 \\
\hline
\end{tabular}

Keterangan: $\mathrm{BM}=$ baku mutu perairan untuk lamun berdasarkan KepMen Lingkungan Hidup No. 51 Tahun 2004 tentang Baku Mutu Air Laut. 
Nilai kerapatan lamun dipengaruhi oleh kualitas perairan sekitarnya sehingga kerapatan akan meningkat pada perairan dengan kondisi yang masih alami (Sembiring et al., 2020). Berdasarkan setiap stasiun maka jenis $C$. rotundata memiliki kerapatan tertinggi pada stasiun 1 dan 2 , sedangkan pada stasiun 3 oleh jenis $T$. hemprichii. Menurut Ganefiani et al. (2019) kedua jenis lamun tersebut merupakan lamun yang mampu tumbuh dengan baik pada substrat pasir kasar dan pecahan karang sehingga kemunculannya lebih banyak dibandingkan jenis lainnya. Hasil kerapatan lamun secara keseluruhan yaitu $295,26 \mathrm{ind} / \mathrm{m}^{2}$ dengan kerapatan tertinggi pada jenis $T$. hemprichii sebesar $125,78 \mathrm{ind} / \mathrm{m}^{2}$ dan kerapatan terendah oleh jenis $E$. acoroides dengan nilai $20,59 \mathrm{ind} / \mathrm{m}^{2}$. Hasil ini berbeda dengan penelitian dari Graha et al. (2016) di Pantai Sanur yang menghasilkan jenis Syringodium isoetifolium memiliki kisaran kerapatan tertinggi sebesar $15-545 \mathrm{ind} / \mathrm{m}^{2}$ dan jenis Cymodocea serrulata memiliki kerapatan terendah sebesar 8-15 ind $/ \mathrm{m}^{2}$. Roelfsema et al. (2014) menyatakan bahwa substrat dasar dan kemampuan adaptasi lamun menyebabkan perbedaan komposisi spesies pada ekosistem lamun. Hasil lengkap terkait kerapatan dan persentase penutupan lamun pada Pantai Pokemon tersaji sebagai berikut (Tabel 2).

Persentase penutupan tertinggi dimiliki oleh jenis $C$. rotundata pada stasiun 1 dan 2, sedangkan jenis $T$. hempricii menjadi lamun dengan tutupan tertinggi pada stasiun 3. Hasil tersebut sama seperti hasil dalam penelitian Ganefiani et al. (2019) bahwa jenis $T$. hemprichii memiliki nilai penutupan tertinggi pada Pelabuhan Karimunjawa dan jenis $C$. rotundata pada Pantai Pancuran. Nilai penutupan di Pantai Pokemon berdasarkan rata-rata ketiga stasiun yaitu $21,29 \%$ dengan jenis $T$. hemprichii menjadi lamun dengan penutupan tertinggi yaitu $8,98 \% H$. ovalis memiliki penutupan terendah sebesar $1,39 \%$. Secara keseluruhan jenis $H$. ovalis memiliki nilai kerapatan lebih besar dari jenis E. acoroides, tetapi memiliki nilai penutupan terendah dari seluruh spesies. Hal ini membuktikan bahwa nilai kerapatan tidak selalu linear dengan nilai penutupan karena pengamatan kerapatan berdasarkan jumlah tegakan sedangkan pengamatan penutupan berdasarkan morfologi daun sehingga daun dengan morfologi yang besar akan semakin menutupi substrat dasar (Hidayat et al., 2018).

Tabel 2. Kerapatan dan persentase penutupan di Pantai Pokemon.

\begin{tabular}{|c|c|c|c|c|c|c|c|c|}
\hline \multirow[b]{2}{*}{ Spesies } & \multicolumn{2}{|c|}{ Stasiun 1} & \multicolumn{2}{|c|}{ Stasiun 2} & \multicolumn{2}{|c|}{ Stasiun 3} & \multicolumn{2}{|c|}{ Rata-rata } \\
\hline & $\begin{array}{c}\text { Kerapatan } \\
\text { (ind } / \mathrm{m}^{2} \text { ) }\end{array}$ & $\begin{array}{c}\text { Tutupan } \\
(\%)\end{array}$ & $\begin{array}{c}\text { Kerapatan } \\
\text { (ind } / \mathrm{m}^{2} \text { ) }\end{array}$ & $\begin{array}{c}\text { Tutupan } \\
(\%)\end{array}$ & $\begin{array}{c}\text { Kerapatan } \\
\text { (ind } / \mathrm{m}^{2} \text { ) }\end{array}$ & $\begin{array}{c}\text { Tutupan } \\
\text { (\%) }\end{array}$ & $\begin{array}{c}\text { Kerapatan } \\
\text { (ind } / \mathrm{m}^{2} \text { ) }\end{array}$ & $\begin{array}{c}\text { Tutupan } \\
\text { (\%) }\end{array}$ \\
\hline E. acoroides & 35,11 & 5,28 & 26,67 & 4,03 & 0 & 0 & 20,59 & 3,10 \\
\hline T. hemprchii & 48,89 & 3,61 & 130,22 & 9,17 & 198,22 & 14,17 & 125,78 & 8,98 \\
\hline C. rotundata & 192,89 & 13,33 & 162,22 & 10,14 & 0 & 0 & 118,37 & 7,82 \\
\hline H. ovalis & 45,78 & 1,94 & 17,33 & 0,83 & 28,44 & 1,39 & 30,52 & 1,39 \\
\hline$\sum$ & 322,67 & 24,16 & 336,44 & 24,17 & 226,66 & 15,56 & 295,26 & 21,29 \\
\hline Kategori & $\begin{array}{l}\text { Sangat } \\
\text { rapat }^{1)}\end{array}$ & Jarang ${ }^{2)}$ & $\begin{array}{l}\text { Sangat } \\
\text { rapat }^{1)}\end{array}$ & Jarang $^{2)}$ & $\begin{array}{l}\text { Sangat } \\
\text { rapat }^{1)}\end{array}$ & Jarang $^{2)}$ & $\begin{array}{l}\text { Sangat } \\
\text { rapat }^{1)}\end{array}$ & Jarang $^{2)}$ \\
\hline
\end{tabular}

Keterangan: 1) = kategori kerapatan lamun berdasarkan Sembiring et al. (2020), 2) = kategori tutupan lamun berdasarkan Rahmawati et al. (2014). 


\subsection{Struktur Komunitas Lamun}

Struktur komunitas lamun menggambarkan kondisi ekologi dari padang lamun di Pantai Pokemon. Berdasarkan hasil penelitian diperoleh nilai indeks keanekaragaman $\left(\mathrm{H}^{\prime}\right)$ dari semua stasiun tergolong rendah. Menurut Rustam et al. (2019b) Pulau Karimunjawa merupakan pulau dengan penduduk terbanyak di Kepulauan Karimunjawa sehingga tekanan ekologisnya sangat besar bagi padang lamun yang dapat berdampak pada rendahnya keanekaragaman spesies. Nilai indeks keseragaman (E) yang diperoleh menunjukkan kategori tinggi pada stasiun 1 sedangkan stasiun 2 dan 3 tergolong sedang. Yusuf et al. (2013) menyatakan bahwa tingginya indeks keseragaman menandakan besarnya persebaran spesies. Perolehan dari hasil indeks dominansi (D) menunjukkan setiap stasiun terdapat spesies yang mendominasi. Hal tersebut membuktikan bahwa nilai indeks dominansi berbanding terbalik dengan nilai indeks keanekaragaman dan indeks keseragaman (Hartati et al., 2017). Hasil perhitungan struktur komunitas lamun tersaji sebagai berikut (Tabel 3).

\subsection{Biomassa Lamun}

Nilai biomassa lamun terbagi menjadi biomassa jaringan atas (daun) dan biomassa jaringan bawah (akar dan rhizoma) (Bagu et al., 2020). Total biomassa lamun dari seluruh jenis lamun yang ditemukan yaitu 74,42 $\mathrm{gbk} / \mathrm{m}^{2}$ dengan biomassa jaringan atas sebesar 35,80 $\mathrm{gbk} / \mathrm{m}^{2}$ dan jaringan bawah lamun sebesar 38,62 gbk $/ \mathrm{m}^{2}$. Lamun jenis $T$. hemprichii memiliki nilai biomassa terbesar di Pantai Pokemon dengan nilai 35,39 $\mathrm{gbk} / \mathrm{m}^{2}$ sedangkan biomassa terendah berada pada jenis E. acoroides sebesar $4,37 \mathrm{gbk} / \mathrm{m}^{2}$. Hasil tersebut berbeda dengan penelitian dari Fifianingrum et al. (2020) yang menghasilkan nilai biomassa terbesar di Perairan Alang-Alang yaitu jenis E. acoroides sebesar $1.811,38 \mathrm{gbk} / \mathrm{m}^{2}$ dan biomassa terendah dari jenis C. rotundata sebesar $25,72 \mathrm{gbk} / \mathrm{m}^{2}$. Nilai biomassa akan berbanding lurus dengan nilai kerapatan sehingga kerapatan spesies berpengaruh terhadap biomassa (Harimbi et al., 2019). Berikut hasil dari biomassa lamun tersaji sebagai berikut (Tabel 4).

Tabel 3. Struktur komunitas lamun di Pantai Pokemon.

\begin{tabular}{ccccccc}
\hline \multirow{2}{*}{ Stasiun } & \multicolumn{2}{c}{ Indeks } & \multicolumn{2}{c}{$\begin{array}{c}\text { Indeks } \\
\text { Keseragaman }\end{array}$} & \multicolumn{2}{c}{$\begin{array}{c}\text { Indeks } \\
\text { Dominansi }\end{array}$} \\
\cline { 2 - 7 } & Heanekaragaman & Kategori & E & Kategori & D & Kategori \\
\hline 1 & 0,84 & Rendah & 0,67 & Tinggi & 0,54 & Dominan \\
2 & 0,62 & Rendah & 0,54 & Sedang & 0,65 & Dominan \\
3 & 0,37 & Rendah & 0,54 & Sedang & 0,77 & Dominan \\
\hline Rata-rata & 0,61 & Rendah & 0,58 & Sedang & 0,65 & Dominan \\
\hline
\end{tabular}

Keterangan: Kategori struktur komunitas lamun berdasarkan Rustam et al. (2019b).

Tabel 4. Biomassa lamun di Pantai Pokemon.

\begin{tabular}{|c|c|c|c|c|c|c|c|c|c|}
\hline \multirow{2}{*}{ Spesies } & \multicolumn{2}{|c|}{ Stasiun 1} & \multicolumn{2}{|c|}{ Stasiun 2} & \multicolumn{2}{|c|}{ Stasiun 3} & \multicolumn{2}{|c|}{ Rata-rata } & \multirow{2}{*}{ Total } \\
\hline & AS & BS & AS & BS & AS & BS & AS & BS & \\
\hline E. acoroides & 4,92 & 4,21 & 2,13 & 1,87 & 0 & 0 & 2,35 & 2,02 & 4,37 \\
\hline T. hemprchii & 4,40 & 7,82 & 18,23 & 18,23 & 23,79 & 33,70 & 15,47 & 19,92 & 35,39 \\
\hline C. rotundata & 19,29 & 21,22 & 17,84 & 16,22 & 0 & 0 & 12,38 & 12,48 & 24,86 \\
\hline H. ovalis & 5,49 & 6,41 & 1,91 & 2,77 & 9,39 & 3,41 & 5,60 & 4,20 & 9,76 \\
\hline$\sum$ & 34,10 & 39,66 & 40,11 & 39,09 & 33,18 & 37,11 & 35,80 & 38,62 & \\
\hline Total & \multicolumn{2}{|c|}{73,76} & \multicolumn{2}{|c|}{79,20} & \multicolumn{2}{|c|}{70,29} & \multicolumn{2}{|c|}{74,42} & \\
\hline
\end{tabular}

Keterangan: $\mathrm{AS}=$ di atas substrat (daun), $\mathrm{BS}=$ di bawah substrat (rizhoma dan akar). 
Menurut Runtuboi et al. (2018) biomassa tersusun dari karbondioksida, hidrogen dan oksigen, tetapi karbon berperan sebagai penyusun terbesar yaitu berkisar 45$50 \%$ berat kering dari suatu biomassa. Hasil penelitian menunjukkan beberapa nilai biomassa jaringan bawah memiliki nilai biomassa lebih rendah dibandingkan jaringan atas. Hal ini dikarenakan besarnya ukuran daun dapat memengaruhi nilai biomassa karena semakin besar ukuran daun maka nilai biomassa akan semakin meningkat (Bagu et al., 2020). Nilai biomassa yang berbeda pada setiap jenis lamun dipengaruhi oleh perbedaan kedalaman, hal ini diperkuat oleh penelitian yang dilakukan Lisdawati et al. (2018) di Pantai Desa Tanjung Tiram bahwa biomassa lamun pada kedalaman $3 \mathrm{~m}$ lebih rendah dibandingkan biomassa lamun di kedalaman $1 \mathrm{~m}$ dan $2 \mathrm{~m}$ sehingga perbedaan kedalaman pada lamun dapat memengaruhi nilai biomassa. Besarnya nilai biomassa pada jaringan bawah lamun berfungsi untuk memperkuat tegakan lamun dalam mencengkram substrat (Rahadiarta et al., 2019).

\subsection{Simpanan Karbon}

Penggunaan metode Loss On Ignition atau pengabuan akan menghasilkan bahan organik seperti karbon, sulfur, nitrogen dan bahan organik lainnya, sehingga perlu dilakukan perhitungan untuk mendapatkan nilai karbon organik (Fourqurean et al., 2012). Karbon organik diperoleh dari hasil kadar bahan organik yang dibagi dengan nilai konstanta bahan organik sebesar 1,724 (Helrich, 1990). Agus et al. (2011) menyatakan bahwa faktor 1/1,724 adalah nilai konversi umum untuk hubungan bahan organik dan karbon dengan cara semi kuantitatif akibat kehilangan berat selama proses pengabuan. Berdasarkan hasil penelitian (Gambar 3) bahwa persentase karbon organik pada bagian jaringan atas jenis $T$. hemprichii lebih besar dibandingkan bagian jaringan bawah di setiap stasiun. Hal ini sesuai dengan pernyataan dari Graha et al. (2016) bahwa umumnya karbon organik pada jaringan bawah substrat akan lebih besar dari jaringan atas substrat.

Simpanan karbon terbesar terdapat pada lamun jenis $T$. hemprichii sebesar 0,10

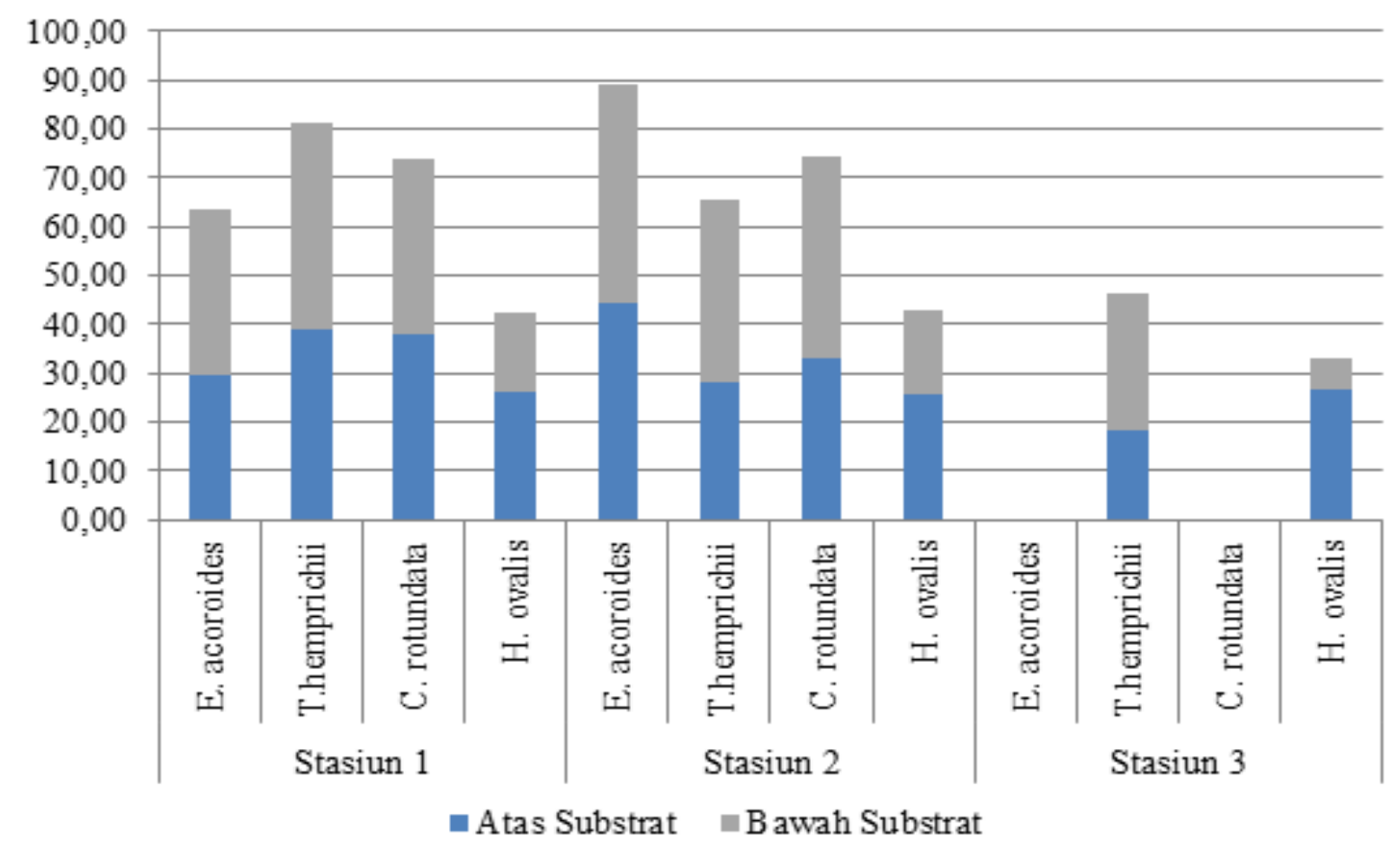

Gambar 3. Persentase karbon organik di Pantai Pokemon. 
ton $\mathrm{C} / \mathrm{ha}$ dengan nilai simpanan karbon bagian atas sebesar 0,0371 ton $\mathrm{C} /$ ha dan pada jaringan bawah sebesar 0,0653 ton $\mathrm{C} / \mathrm{ha}$. Secara keseluruhan simpanan karbon di Pantai Pokemon dalam penelitian ini yaitu 0,23 ton $\mathrm{C} / \mathrm{ha}$ dengan simpanan karbon jaringan atas bernilai 0,1039 ton $\mathrm{C} / \mathrm{ha}$ dan simpanan di jaringan bawah sebesar 0,1265 ton $\mathrm{C} /$ ha. Hasil tersebut lebih rendah dari hasil penelitian Rahadiarta et al. (2019) yang menunjukkan simpanan karbon tertinggi di Pantai Mengiat oleh jenis Thalassodendron ciliatum sebesar 0,6246 ton $\mathrm{C} /$ ha dan total simpanan karbon mencapai 0,4288 ton $\mathrm{C} /$ ha dengan simpanan pada jaringan bawah sebesar 0,257 ton $\mathrm{C} /$ ha dan jaringan atas sebesar 0,1718 ton $\mathrm{C} /$ ha. Simpanan karbon pada lamun dipengaruhi oleh beberapa faktor seperti besarnya kandungan biomassa lamun, faktor lingkungan seperti suhu, dan jenis substrat (Hartati et al., 2017). Hal ini didukung oleh Bagu et al. (2020) yang menyatakan simpanan karbon pada jaringan bawah lebih besar dibandingkan jaringan atas karena berkaitan dengan biomassa pada bagian rhizoma yang mencapai 60-80\%. Akan tetapi, berdasarkan hasil penelitian terlihat bahwa nilai simpanan karbon jaringan atas pada jenis $E$. acoroides dan $H$. ovalis lebih besar dibandingkan nilai simpanan karbon pada jaringan bawah. Hasil ini seperti yang terjadi dalam penelitian Indriani et al. (2017) bahwa simpanan karbon lamun bagian atas di Pulau Bintan lebih besar dari simpanan karbon bagian bawah dikarenakan penyerapan karbon lebih banyak terjadi pada bagian atas yaitu daun melalui proses fotosintesis. Berikut hasil dari simpanan karbon pada lamun yang tersaji sebagai berikut (Tabel 5).

Total stok karbon lamun berbanding lurus dengan luas area lamun sehingga semakin luas padang lamun akan membuat potensi penyerapan karbon pada lamun semakin besar yang akan meningkatkan nilai stok karbon (Harimbi et al., 2019). Berdasarkan hasil penelitian padang lamun di Pantai Pokemon memiliki luas 4,903 ha dengan total stok karbon sebesar 1,13 ton $\mathrm{C}$ yang terdiri dari stok karbon pada jaringan atas sebesar 0,51 ton $\mathrm{C}$ dan pada bagian jaringan bawah bernilai 0,62 ton $C$. Hasil tersebut lebih rendah dari hasil penelitian Ganefiani et al. (2019) di Pelabuhan Karimunjawa dan di Pantai Pancuran yang masing-masing memiliki total stok karbon 1,28 ton $\mathrm{C}$ dan 2,49 ton $\mathrm{C}$. Jenis lamun yang memiliki total stok karbon tertinggi yaitu $T$. hemprichii dengan nilai 0,50 ton $\mathrm{C}$, sedangkan jenis $E$. acoroides merupakan jenis lamun dengan total stok karbon terendah yaitu 0,08 ton $\mathrm{C}$. Hal ini dikarenakan adanya perbedaan nilai biomassa dan kemampuan setiap jenis lamun dalam menyerap dan menyimpan karbon (Khairunnisa et al., 2018). Stok karbon lamun pada jaringan bawah substrat umumnya lebih besar dibandingkan stok

Tabel 5. Estimasi simpanan karbon di Pantai Pokemon.

\begin{tabular}{|c|c|c|c|c|c|c|c|c|c|c|}
\hline \multirow{2}{*}{ Spesies } & \multicolumn{2}{|c|}{ Stasiun 1} & \multicolumn{2}{|c|}{ Stasiun 2} & \multicolumn{2}{|c|}{ Stasiun 3} & \multicolumn{2}{|c|}{ Rata-rata } & \multirow{2}{*}{$\begin{array}{c}\text { Total } \\
\left(\mathrm{gC} / \mathrm{m}^{2}\right)\end{array}$} & \multirow{2}{*}{$\begin{array}{c}\text { Total } \\
\text { (tonC/ha) }\end{array}$} \\
\hline & AS & $\mathrm{BS}$ & AS & $\mathrm{BS}$ & AS & $\mathrm{BS}$ & $\mathrm{AS}$ & $\mathrm{BS}$ & & \\
\hline E. acoroides & 1,45 & 1,44 & 0,95 & 0,83 & 0,00 & 0,00 & 0,80 & 0,76 & 1,56 & 0,02 \\
\hline T. hemprchii & 1,72 & 3,29 & 5,12 & 6,82 & 4,30 & 9,49 & 3,71 & 6,53 & 10,24 & 0,10 \\
\hline C. rotundata & 7,30 & 7,61 & 5,91 & 6,73 & 0,00 & 0,00 & 4,40 & 4,78 & 9,18 & 0,09 \\
\hline H. ovalis & 1,43 & 1,04 & 0,49 & 0,48 & 2,51 & 0,21 & 1,48 & 0,58 & 2,06 & 0,02 \\
\hline$\sum\left(\mathrm{gC} / \mathrm{m}^{2}\right)$ & 11,90 & 13,38 & 12,47 & 14,86 & 6,81 & 9,70 & 10,39 & 12,65 & 23,04 & 0,23 \\
\hline Total $\left(\mathrm{gC} / \mathrm{m}^{2}\right)$ & 25 & & 27, & 33 & & & 23, & 04 & & \\
\hline Total (ton/ha) & 0 & & 0, & & & & 0, & 23 & & \\
\hline
\end{tabular}

Keterangan: $\mathrm{AS}=$ di atas substrat (daun), $\mathrm{BS}=$ di bawah substrat (rhizoma dan akar). 


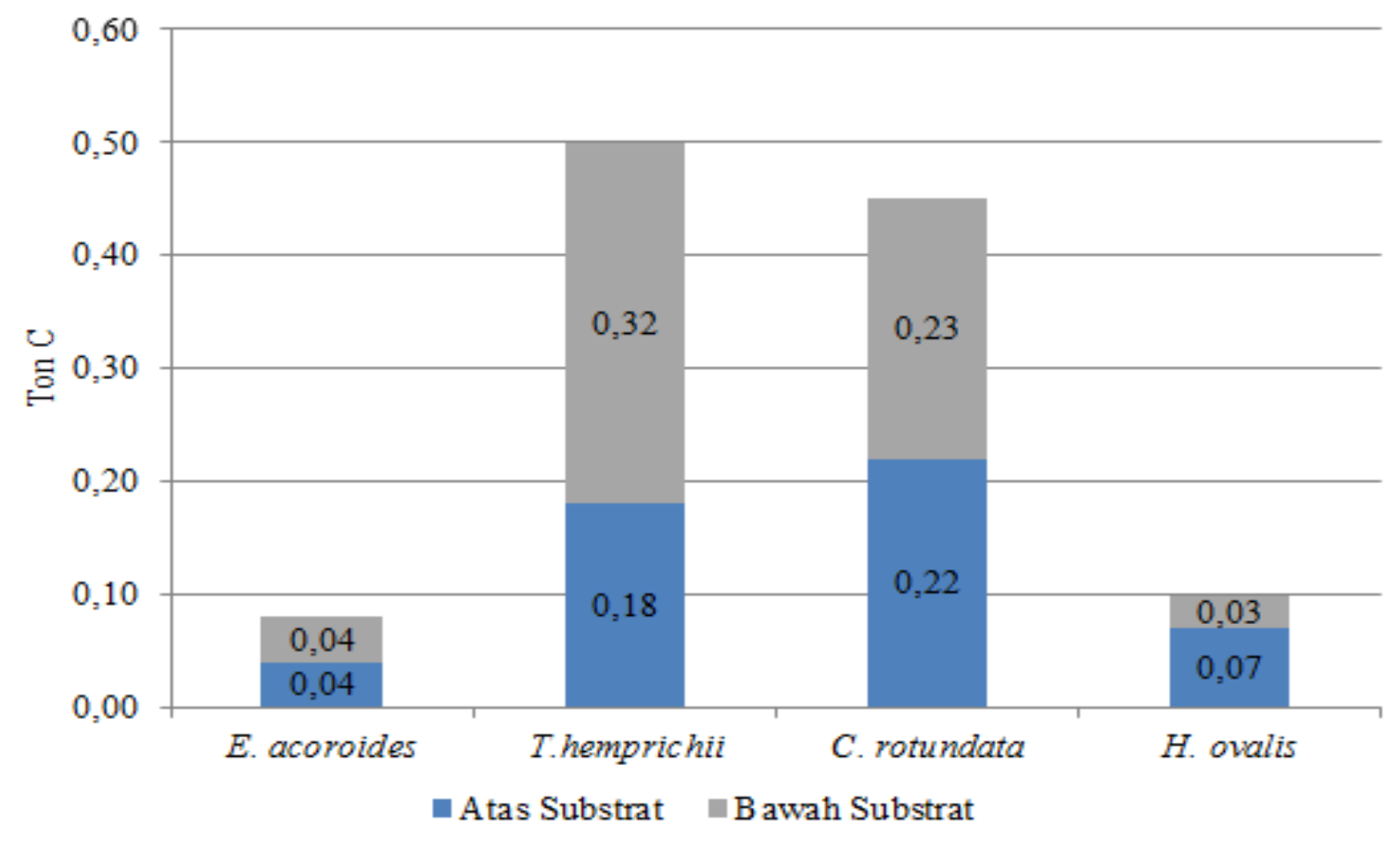

Gambar 4. Stok karbon lamun di Pantai Pokemon.

karbon jaringan atas seperti pada jenis lamun $T$. hemprichii dan $C$. rotundata dalam penelitian ini. Hal tersebut sesuai dengan hasil penelitian dari Fifianingrum et al. (2020) bahwa hasil karbon lamun jaringan bawah lebih tinggi karena jaringan bawah substat lebih rendah terdampak gangungan lingkungan dari gelombang, arus dan kegiatan antropogenik sehingga karbon hasil fotosintesis dapat terus terakumulasi. Hasil stok karbon tersaji sebagai berikut (Gambar $1)$.

\section{KESIMPULAN}

Berdasarkan hasil yang telah diperoleh dapat disimpulkan bahwa ditemukan lamun jenis $E$. acoroides, $T$. hemprichii, $C$. rotundata, dan $H$. ovalis di Pantai Pokemon dengan kondisi perairan masih tergolong baik karena sesuai dengan baku mutu untuk pertumbuhan lamun meskipun jenis $T$. hemprichii mendominasi. Nilai total biomassa dari semua jenis lamun yaitu $74,42 \mathrm{gbk} / \mathrm{m}^{2}$ dengan total biomassa jaringan atas sebesar 35,80 $\mathrm{gbk} / \mathrm{m}^{2}$ dan jaringan bawah sebesar $38,62 \mathrm{gbk} / \mathrm{m}^{2}$. Total simpanan karbon lamun pada Pantai Pokemon sebesar 0,23 ton $\mathrm{C} /$ ha dengan total simpanan karbon jaringan atas sebesar 0,1039 ton $\mathrm{C} / \mathrm{ha}$ dan jaringan bawah sebesar 0,1265 ton C/ha. Total stok karbon di Pantai Pokemon dalam luasan padang lamun 4,903 ha yaitu sebesar 1,130 ton $\mathrm{C}$ dengan stok karbon jaringan atas bernilai 0,510 ton $\mathrm{C}$ dan jaringan bawah 0,620 ton $\mathrm{C}$.

\section{UCAPAN TERIMAKASIH}

Penulis mengucapkan terimakasih kepada Balai Taman Nasional Karimunjawa (BTNKJ) serta kepada Direktorat Riset dan Pengabdian Masyarakat, Deputi Bidang Penguatan Riset dan Pengembangan, Kementerian Riset dan Teknologi Badan Riset dan Inovasi Nasional, Tahun Anggaran 2020, Skema Penelitian Dasar Nomor: 22565/UN7.6.1/PP/2020.

\section{DAFTAR PUSTAKA}

Agus, F., K. Hariah, \& A. Mulyani. 2011. Pengukuran cadangan karbon tanah gambut. petunjuk praktis. World 
Agroforesty Centre-ICRAF, SEA Regional Office dan Balai Besar dan Pengembangan Sumberdaya Lahan Pertanian (BBSDLP). Bogor. 58 p.

Aji, F.B., S. Febrianto, \& N. Afiati. 2020. Estimasi stok karbon di padang lamun pulau nyamuk dan pulau kemujan, Balai Taman Nasional Karimunjawa, Jepara. J. Ilmu dan Teknoogi Kelautan Tropis, 12(3): 805-819. https://doi.org/10.29244/jitkt.v12i3.31 505

Allifah, A.N. \& T. Rosmawati. 2018. Hubungan kerapatan lamun dengan kepadatan Bivalvia di pesisir Pantai Ori Kecamatan Pulau Haruku. $J$. Biology Science \& Education, 7(1): 81-96. https://doi.org/10.33477/bs.v7i1.395

Badan Standar Nasional (SNI 7724). 2011. Pengukuran dan perhitungan cadangan karbon-pengukuran lapangan untuk penaksiran cadangan karbon hutan (ground based forest carbon accounting). Badan Standar Nasional. Jakarta. 16 p.

Bagu, I.A., M.S. Hamidun, \& D.W.K. Baderan. 2020. Estimasi simpanan karbon lamun Enhalus acoroides di Kawasan Pantai Langala Dulupi Kabupaten Boalemo. Jambura Edu Biosfer J., 2(1): 13-21. https://doi.org/10.34312/jebj

Bayu, R., J. Waluyo, \& M. Iqbal. 2018. Pengembangan alat kondensasi pengukur oksigen udara ambien untuk mendukung praktikum pada mata kuliah pengetahuan lingkungan. Saintifika, 20(1): 11-22. https://jurnal.unej.ac.id/index.php/ST F/article/view/9773

Fifianingrum, K.P.N.D., H. Endrawati, \& I. Riniatsih. 2020. Simpanan karbon pada ekosistem lamun di Perairan Alang-Alang dan Perairan Pancuran Karimunjawa, Jawa Tengah. J. of Marine Reasearch, 9(3): 289-295. https://doi.org/10.14710/jmr.v9i3.275 58

Fourqurean, J.W., C.M. Duarte, H. Kennedy, N. Marba, M. Holmer, M.A. Mateo, E. Apostolaki, G.A. Kendrick, D. Krause-Jensen, K.J. McGlathery, \& O. Serrano. 2012. Seagrass ecosystems as a globally significant carbon stock. Nature Geoscience, 5: 505-509.

https://doi.org/10.1038/ngeo1477

Ganefiani, A., S. Suryanti, \& N. Latifah. 2019. Potensi padang lamun sebagai penyerap karbon di perairan Pulau Karimunjawa, Taman Nasional Karimunjawa. Saintek Perikanan (Indonesian J. of Fisheries Science and Technology), 14(2): 115-122. https://doi.org/10.14710/ijfst.14.2.115 $-122$

Graha, Y.I., I.W. Arthana, \& I.W.G.A. Karang. 2016. Simpanan Karbon padang lamun di kawasan Pantai Sanur, Kota Denpasar. Ecotrophic: J. Ilmu Lingkungan (J. of Environmental Science), 10(1): 4653. https://doi.org/10.24843/EJES.2016.v 10.i01.p08

Harimbi, K.A., N. Taufiq-Spj, \& I. Riniatsih. 2019. Potensi penyimpanan karbon pada lamun spesies Enhalus acoroides dan Cymodocea serrulata di Perairan Jepara. Buletin Oseanografi Marina, 8(2): 109-115. https://doi.org/10.14710/buloma.v8i2. 23657

Hartati, R., I. Pratikto, \& T.N. Pratiwi. 2017. Biomassa dan estimasi simpanan karbon pada ekosistem padang lamun di Pulau Menjangan Kecil dan Pulau Sintok, Kepulauan Karimunjawa. Buletin Oseanografi Marina, 6(1): 74-81.

https://doi.org/10.14710/buloma.v6i1. 15746

Helrich, K. 1990. Method of Analysis of the association of official analytical 
chemists. Fifteenth Edition. Virginia. $1298 \mathrm{p}$.

https://doi.org/10.3109/15563657608 988149

Hidayah, H., M. Fauzi, \& A. Adriman., 2019. Types and density of seagrass in The Genting Beach, Tanjung Medang Village, Rupat Utara District, Bengkalis Regency, Riau Province. Asian J. Aquatic Sciences, 2(2): 199126.

https://doi.org/10.31258/ajoas.2.2.199 $-126$

Hidayat, W., I.W.S. Warpala, \& N.P.S.R. Dewi. 2018. Komposisi jenis lamun (seagrass) dan karakteristik biofisik perairan di kawasan Pelabuhan Desa Celukanbawang Kecamatan Gerokgak Kabupaten Buleleng Bali. J. Pendidikan Biologi Undiksha, 5(3): 133-145.

https://doi.org/10.23887/jjpb.v5i3.219 66.g13576

Indriani., A.J. Wahyudi, \& D. Yona. 2017. Cadangan karbon di area padang lamun pesisir Pulau Bintan, Kepulauan Riau. Oseanologi dan Limnologi di Indonesia, 2(3): 1-11. https://doi.org/10.14203/oldi.2017.v2i 3.99

Keputusan Menteri Negara Lingkungan Hidup Nomor 51. 2004. Baku mutu air laut. MENLH. Jakarta. 13 p. http://www.kelair.bppt.go.id/Hukum/ data/kepmen/bml/51-2004.pdf

Khairunnisa., I. Setyobudiandi, \& M. Boer. 2018. Estimasi cadangan karbon pada lamun di pesisir timur Kabupaten Bintan. J. Ilmu dan Teknologi Kelautan Tropis, 10(3): 639-650. https://doi.org/10.29244/jitkt.v10i3.21 397

Lisdawati., S.W. Ahmad, \& L.O. Siwi. 2018. Studi biomassa lamun (Enhalus acoroides L.) dan (Halodule pinifolia) berdasarkan kedalaman air laut di Pantai Desa Tanjung Tiram
Sulawesi Tenggara. Biowallacea, 5(2): 861-870.

https://doi.org/10.33772/biowallacea. v5i2.5878

Mashoreng, S., M.B. Selamat, K. Amri, \& Y.A.L. Nafie. 2018. Hubungan antara persen penutupan dan simpanan karbon lamun. J. Akuatika Indonesia, 3(1): 74-83.

https://doi.org/10.24198/jaki.v3i1.234 37

Oktamalia., D. Purnama, \& D. Hartono. 2016. Studi jenis dan kelimpahan teripang (Holothuroidea) di ekosistem padang lamun perairan Desa Kahyapu Pulau Enggano. J. Enggano, 1(1): 9-17. https://doi.org/10.31186/jenggano.1.1 .9-17

Prasetyawan, I.B., L. Maslukah, \& A. Rifai. 2017. Pengukuran sistem karbon dioksida $\left(\mathrm{CO}_{2}\right)$ sebagai data dasar penentuan fluks karbon di Perairan Jepara. Buletin Oseanografi Marina, 6(1): 9-16.

https://doi.org/10.14710/buloma.v6i1. 15736

Rahadiarta, I.K.V.S., I.D.N.N. Putra, \& Y. Suteja. 2019. Simpanan karbon pada padang lamun di kawasan Pantai Mengiat, Nusa Dua Bali. J. of Marine and Aquatic Sciences, 5(1): 1-10. https://doi.org/10.24843/jmas.2019.v0 5.101.p01

Rahmawati, S., A. Irawan., I.H. Supriyadi, \& M.H. Azkab. 2014. Panduan monitoring padang lamun. Cet 1 . COREMAP CTI LIPI. Jakarta. 37 p.

Roelfsema, C.M., M. Lyons, E.M. Kovacs, P. Maxwell, M.I. Saunders, J.S. Villareal, \& S.R. Phinn. 2014. Multitemporal mapping of seagrass cover, species and biomass: a semiautomated object based image analysis approach. Remote Sensing of Environment, 150: 172-187.

https://doi.org/10.1016/j.rse.2014.05. 001 
Runtuboi, F., J. Nugroho, \& Y. Rahakratat. 2018. Biomassa dan penyerapan karbon oleh lamun Enhalus acroides di pesisir Teluk Gunung Botak Papua Barat. J. Sumberdaya Akuatik Indopasifik, 2(2): 91-102.

https://doi.org/10.30862/jsai-fpikunipa.2018.Vol.2.No.2.47

Rustam, A., N.S. Adi., A. Daulat., W. Kiswara., D.S. Yusup, \& R.A. Rappe. 2019a. Pedoman pengukuran karbon di ekosistem padang lamun. Cet 1. ITB Press. Bandung. 109 p.

Rustam, A., Y.P.R. Ningsih, D.D. Suryono, A. Daulat, \& H.L. Salim. 2019b. Dinamika struktur komunitas lamun Kepulauan Karimunjawa, Kabupaten Jepara. J. Kelautan Nasional, 14(3): 179-190. https://doi.org/10.15578/jkn.v14i3.77 61

Samson, E., D. Kasale, \& D. Wakano. 2020. Kajian kondisi lamun pada perairan Pantai Waemulang Kabupaten Buru Selatan. J. Biology Science \& Education, 9(1): 11-25. https://doi.org/10.33477/bs.v9i1.1313 Sembiring, Y.T.B., A. Hartoko, \& N. Latifah. 2020. Analisis sebaran klorofil-a lamun di Pantai Pokemon dan Bobby di Karimunjawa menggunakan citra satelit Sentinel-2A. Management Aquatic Resources J. of Maquares, 9(2): 115-122.

https://doi.org/10.14710/marj.v9i2.27 767
Setiawati, T., M. Alifah, A.Z. Mutaqin, M. Nurzaman, B. Irawan, \& R. Budiono. 2018. Studi morfologi beberapa jenis lamun di Pantai Timur dan Pantai Barat, Cagar Alam Pangandaran. J. Por-Life, 5(1): 487-495. http://ejournal.uki.ac.id/index.php/pro life/article/view/526

Wicaksono, S.G., Widianingsih, \& S.T. Hartati. 2012. Struktur vegetasi dan kerapatan jenis lamun di perairan Kepulauan Karimunjawa Kabupaten Jepara. J. of Marine Research, 1(2): 1-7.

https://doi.org/10.14710/jmr.v1i2.201 6

Yunitha, A., Y. Wardiatno, \& F. Yulianda. 2014. Diameter substrat dan jenis lamun di pesisir Bahoi Minahasa Utara: sebuah analisis korelasi. $J$. Ilmu Pertanian Indonesia (JIPI), 19(3): 130-135.

https://journal.ipb.ac.id/index.php/JIP I/article/download/9146/7191/

Yusuf, M., Y. Koniyo, \& C. Panigoro. 2013. Keanekaragaman lamun di perairan sekitar Pulau Dudepo Kecamatan Anggrek Kabupaten Gorontalo Utara. Nikè: J. Ilmiah Perikanan dan Kelautan, 1(1): 18-25. http://ejurnal.ung.ac.id/index.php/nike /article/view/1212/962

Submitted: 16 December 2021

Reviewed : 11 February 2021

Accepted : 16 August 2021

\section{FIGURE AND TABEL TITLES}

Figure 1. Research location, Karimunjawa 2020.

Figure 2. Placement of line and kuadrant transect.

Figure 3. Organic carbon content (\%) in Pokemon Beach.

Figure 4. Carbon stock of seagrass at Pokemon Beach.

Table 1. Pokemon Beach water quality parameters.

Table 2. Density and percentage of seagrass cover in Pokemon Beach.

Table 3. The structure of the seagrass community in Pokemon Beach.

Table 4. Seagrass biomass in Pokemon Beach.

Table 5. Estimated seagrass carbon storage in Pokemon Beach. 